\title{
Study on Intercropping of Fenugreek (Trigonellafoenum graecum L.) with Different Short Duration Vegetable Crops
}

\author{
Akansha Verma*, Kavita Aravindakshan, Sh. Rajesh Kumar Sharma, \\ Anil K. Gupta, Rahul Chopra and I. B. Maurya
}

Department of Vegetable Science, College of Horticulture and Forestry, Jhalarapatan, Jhalawar-326023, Rajasthan, India

*Corresponding author

\section{Keywords}

Vegetables, density, planting date, resources, pests, diseases and weeds

Article Info

\section{Accepted:}

12 April 2021

Available Online:

10 May 2021
A field experiment entitled "Study on intercropping of fenugreek (Trigonellafoenum graecum L.) with different short duration vegetables" was conducted at the vegetable farm, Department of Vegetable Science, College of Horticulture and Forestry, Jhalrapatan City, Jhalawar during rabi season 2019-20. The experiment comprised of four sole crops (fenugreek, carrot, cabbage and radish) and fenugreek intercropped with carrot, cabbage and radish with three ratios 1:1, 1:2 and 2:2 with a total of thirteen treatments each replicated thrice and laid out in randomized block design. The result shows that the sole crops viz., fenugreek, carrot, cabbage and radish had significant effect on growth, yield and quality over different intercropping system. Maximum plant height $(72.73 \mathrm{~cm})$, number of leaves $(81.33)$, chlorophyll content in leaves $(1.70 \mathrm{mg} / 100 \mathrm{~g})$, number of pods per plant $(52.75)$, length of pod $(10.36 \mathrm{~cm})$, number of seeds per pod (12.47), seed yield per plant (10.33 g), seed yield per plot $(1.24 \mathrm{~kg})$, estimated yield (34.55 q/ha) and per cent crude protein content of seed (21.86) of fenugreek was obtained in $\mathrm{T}_{1}$ (fenugreek sole) over $\mathrm{T}_{9}$ (fenugreek + cabbage 1:2). However, $\mathrm{T}_{5}$ (fenugreek + carrot 1:1) treatment was found at par with $\mathrm{T}_{1}$ in respect of number of leaves (78), chlorophyll content in leaves $(1.60 \mathrm{mg} / 100 \mathrm{~g})$, number of pods per plant $(50.46)$, length of pod $(9.68 \mathrm{~cm})$, number of seeds per pod (11.68), seed yield per plant (9.83 g), estimated yield (32.83 q/ha) and per cent crude protein content (20.66) of fenugreek.

\section{Introduction}

Intercropping is a ways to enhance diversity in an agricultural ecosystem. Intercropping as an example of sustainable agricultural systems following objectives such as: ecological balance, more utilization of resources, increasing the quantity and quality and reduce yield damage to pests, diseases and weeds. Success of intercrops in comparison with a pure cropping can be determined by a series of agronomic operations that interactions 
between the species will be affected by them. These operations are including ultimate density, planting date, resources availability and intercropping models (Mazaheri et al., 2006; Gliessman, 1997; Hatfield and Karlen, 1993). Owing to the importance of intercropping of vegetables and doubling the farmers income as it is an urgent need for today's demand and fenugreek being the major crop of Rajasthan, a study on fenugreek based intercropping with vegetables is necessary to be taken up. Intercropping with legumes makes effective use of land and other resources and results in reduced cost of production. Increased agricultural production through intercropping with minimal cost is need of time to feed increasing population.

Vegetables are an important food crops playing a greater role in food trade in India. Fenugreek is treated as spice as well as legume crop. It is annual herbaceous and autogamous crop associated with family fabaceae and sub family papillionaceae. Cabbage (Brassica oleracea L. var. capitata F.) is an important cole crop, belonging to family cruciferae, is rich in phyto nutrients and antioxidants. An attempt was made to incorporate some short duration winter vegetables of different rooting depth with fenugreek for additional return with more cropping intensity. Due to different growth habit and rooting depth the intercrops did not compete for vertical and horizontal resources with the main crop i.e. Fenugreek. Radish (Raphanus sativus L.) is one of the most popular root crop of Rabi season and is widely acclaimed for its excellent nutritive and medicinal values. It belongs to family Cruciferae.

It is popular in both tropical and temperate countries. Radish is grown throughout the country and throughout the year. It is easily grown as a companion crop or intercrop between the rows of other vegetable.
Therefore, the present study entitled "Study on intercropping of fenugreek (Trigonellafoenum graecum L.) with different short duration vegetable crops" was carried out with an object to compare the growth, yield and quality of fenugreek under intercropping system with sole cropping system.

\section{Materials and Methods}

The field experiment on growth, yield and quality of fenugreek as influenced by different intercropping ratios was conducted at the vegetable farm, Department of Vegetable Science, College of Horticulture and Forestry, Jhalrapatan City, Jhalawar during rabi season 2019-20.The experiment comprising of thirteen treatments viz., sole fenugreek, sole carrot, sole cabbage, sole radish, fenugreek + carrot (1:1), fenugreek + carrot (1:2), fenugreek + carrot (2:2), fenugreek + cabbage(1:1), fenugreek + cabbage (1:2), fenugreek + cabbage $(2: 2)$, fenugreek + radish (1:1), fenugreek + radish (1:2) and fenugreek + radish (2:2) was laid in randomized block design with three replications. Ajmer Fenugreek-3 was sown using $25 \mathrm{~kg}$ seeds at row to row spacing of $30 \mathrm{~cm}$. The carrot (Pusa Yamdagini), cabbage (Pusa Mukta) and radish (Japanese White) were sown at row spacing of $30 \mathrm{~cm}$. A uniform recommended doses of 30 $\mathrm{Kg} \mathrm{N}$ and $20 \mathrm{~kg} \mathrm{P}_{2} \mathrm{O}_{5} \mathrm{ha}^{-1}$ and $20 \mathrm{~kg} \mathrm{~K} 2 \mathrm{O}$ for sole fenugreek, $90 \mathrm{~kg} \mathrm{~N}, 50 \mathrm{~kg} \mathrm{P}_{2} \mathrm{O}_{5}$ and $40 \mathrm{~kg}$ $\mathrm{K}_{2} \mathrm{O}$ for sole carrot, $100 \mathrm{~kg} \mathrm{~N}, 125 \mathrm{~kg} \mathrm{P}_{2} \mathrm{O}_{5}$ and $25 \mathrm{~kg} \mathrm{~K} \mathrm{~K}_{2} \mathrm{O}$ for sole cabbage and $50 \mathrm{~kg} \mathrm{~N}$, $100 \mathrm{~kg} \mathrm{P}_{2} \mathrm{O}_{5}$ and $50 \mathrm{~kg} \mathrm{~K}_{2} \mathrm{O}$ for sole radish was applied. In intercropping $100 \%$ and $50 \%$ of recommended RDF of intercrops were applied along with RDF of base crop. 1/3 N and full dose of $\mathrm{P}$ and $\mathrm{K}$ was applied as basal dose at the time of sowing and remaining $2 / 3$ $\mathrm{N}$ was applied in two equal split at 30 and 60 DAS. The standard agronomic practices were followed for raising healthy crop of fenugreek as well as carrot, cabbage and radish. Irrigation was applied as per requirement of 
fenugreek, which met the demand of intercrops also. The observation on growth, yield and quality parameters fenugreek was recorded. Harvesting of fenugreek was done in stages keeping in view the maturity of pods.

\section{Results and Discussion}

\section{Growth parameters of fenugreek}

The result of present investigation showed that intercropping of fenugreek with different short duration vegetables viz. carrot, cabbage and radish had significant effect on the plant height, number of leaves and chlorophyll content in leaves of fenugreek for sole crop over different intercropping systems. The sole crop had maximum growth parameters i.e. plant height $(72.73 \mathrm{~cm})$, number of leaves (81.33) and chlorophyll content in leaves (1.70 $\mathrm{mg} / 100 \mathrm{~g}$ ) and the minimum value of growth parameters i.e. plant height $(51.11 \mathrm{~cm})$, number of leaves (65.67)and chlorophyll content in leaves $(1.35 \mathrm{mg} / 100 \mathrm{~g})$ were recorded under treatment $\mathrm{T}_{9}$ (fenugreek + cabbage 1:2). However, intercropping of fenugreek in 1:1 ratio with carrot i.e. treatment $\mathrm{T}_{5}$ (fenugreek + carrot 1:1) was found at par with treatment $T_{1}$ (fenugreek sole). These results are conformity with the research of Kumar et al., (2006) in fennel intercropping with cauliflower and radish, Mehta et al., (2010) in coriander intercropping system, Verghese (2013) in cabbage intercropping system, Wasaya et al., (2013) in wheat and fenugreek intercropping system and Mehta et al., (2015) in fennel based intercropping system. Maximum values for most of the yield parameters in sole fenugreek may be attributed to efficient utilization of space and light interception along with nutrient uptake and availability of applied nutrients which ultimately increased the production of assimilates and the rate of biosynthesis of various metabolic activities leading to increased rate of growth and development, which is expressed in higher yield (Choudhary and Jana, 2012).

\section{Yield attributes and yields of fenugreek}

Intercropping of fenugreek with different vegetables viz. carrot, cabbage and radish significantly influenced the sole crop as compared to different intercropping systems on the yield parameters of fenugreek like number of pods per plant, number of seed per pod, length of pod, seed yield per plant, seed yield per plot and estimated yield.

The sole crop of fenugreek had maximum value of yield attributes i.e. number of pods per plant $(52.75)$, length of pod $(10.36 \mathrm{~cm})$, number of seeds per pod (12.47), seed yield per plant (10.33 g), seed yield per plot (1.24 $\mathrm{kg})$, estimated yield (34.55 q/ha) of fenugreek and minimum value for yield attributes i.e. number of pods per plant (43.69), length of pod $(6.29 \mathrm{~cm})$, number of seed per pod (9.12), seed yield per plant $(8.16 \mathrm{~g})$, seed yield per plot $(0.98 \mathrm{~kg})$ and estimated yield $(27.15 \mathrm{q} / \mathrm{ha})$ were recorded under treatment $\mathrm{T}_{9}$. However, treatment $\mathrm{T}_{5}$ (fenugreek + carrot 1:1), $\mathrm{T}_{7}$ (fenugreek + carrot $\left.2: 2\right), \mathrm{T}_{11}$ (fenugreek + radish 1:1), $\mathrm{T}_{6}$ (fenugreek + carrot 1:2) and $\mathrm{T}_{8}$ (fenugreek + cabbage 1:1)were found at par with sole fenugreek i.e. treatment $\mathrm{T}_{1}$.

These results are conformity with the research of Rana et al., (1996) in intercropping of chickpea with mustard, Kumar et al., (2006) in intercropping of fennel with potato, cauliflower and radish, Tripathi and Dwivedi (2009) in fennel + cauliflower intercropping system and Mehta et al., (2015) in fennel intercropping system. In sole fenugreek the higher yield and yield attributes of fenugreek was obtained due to no competition for resources with any other crop except fenugreek leading to better absorption of nutrient and water by fenugreek. 
Table.1 Effect of intercropping system of growth parameters of fenugreek

\begin{tabular}{|c|c|c|c|c|}
\hline $\begin{array}{c}\text { Treatment } \\
\text { notation }\end{array}$ & Treatments & $\begin{array}{l}\text { Plant height } \\
\text { (cm) }\end{array}$ & $\begin{array}{l}\text { Number of } \\
\text { leaves }\end{array}$ & $\begin{array}{l}\text { Total Chlorophyll } \\
\text { content } \\
\text { (mg/100 g) }\end{array}$ \\
\hline $\mathbf{T}_{1}$ & Fenugreek & 72.73 & 81.33 & 1.70 \\
\hline $\mathbf{T}_{2}$ & Carrot & - & - & - \\
\hline $\mathbf{T}_{\mathbf{3}}$ & Cabbage & - & - & - \\
\hline $\mathbf{T}_{4}$ & Radish & - & - & - \\
\hline $\mathbf{T}_{5}$ & Fenugreek + Carrot (1:1) & 66.83 & 78.00 & 1.60 \\
\hline $\mathbf{T}_{6}$ & Fenugreek + Carrot (1:2) & 64.67 & 74.33 & 1.54 \\
\hline $\mathbf{T}_{7}$ & Fenugreek + Carrot (2:2) & 65.07 & 75.00 & 1.59 \\
\hline $\mathbf{T}_{8}$ & Fenugreek + Cabbage (1:1) & 59.76 & 68.67 & 1.45 \\
\hline $\mathbf{T}_{9}$ & Fenugreek + Cabbage (1:2) & 51.11 & 65.67 & 1.35 \\
\hline $\mathbf{T}_{10}$ & Fenugreek + Cabbage (2:2) & 56.80 & 66.00 & 1.41 \\
\hline $\mathbf{T}_{11}$ & Fenugreek + Radish (1:1) & 63.96 & 73.67 & 1.56 \\
\hline $\mathbf{T}_{12}$ & Fenugreek + Radish (1:2) & 59.36 & 69.67 & 1.44 \\
\hline $\mathbf{T}_{13}$ & Fenugreek + Radish (2:2) & 62.57 & 73.00 & 1.46 \\
\hline S.Em \pm & & 1.77 & 1.93 & 0.05 \\
\hline CD $5 \%$ & & 5.20 & 5.67 & 0.14 \\
\hline
\end{tabular}

Table.2 Effect of intercropping system of yield parameters of fenugreek

\begin{tabular}{|c|c|c|c|c|}
\hline $\begin{array}{c}\text { Treatment } \\
\text { notation }\end{array}$ & Treatments & $\begin{array}{c}\text { Number of } \\
\text { pods per plant }\end{array}$ & $\begin{array}{c}\text { Length of } \\
\operatorname{pod}(\mathrm{cm})\end{array}$ & $\begin{array}{c}\text { Number of } \\
\text { seeds per } \\
\text { pod }\end{array}$ \\
\hline $\mathbf{T}_{1}$ & Fenugreek & 52.75 & 10.36 & 12.47 \\
\hline $\mathbf{T}_{2}$ & Carrot & - & - & - \\
\hline $\mathbf{T}_{3}$ & Cabbage & - & - & - \\
\hline $\mathbf{T}_{4}$ & Radish & - & - & - \\
\hline $\mathbf{T}_{\mathbf{5}}$ & Fenugreek + Carrot $(1: 1)$ & 50.46 & 9.68 & 11.68 \\
\hline $\mathbf{T}_{6}$ & Fenugreek + Carrot (1:2) & 46.66 & 8.15 & 10.86 \\
\hline $\mathbf{T}_{7}$ & Fenugreek + Carrot (2:2) & 49.85 & 8.79 & 11.57 \\
\hline $\mathbf{T}_{8}$ & Fenugreek + Cabbage (1:1) & 45.28 & 6.77 & 9.87 \\
\hline $\mathbf{T}_{9}$ & Fenugreek + Cabbage (1:2) & 43.69 & 6.29 & 9.12 \\
\hline $\mathbf{T}_{10}$ & Fenugreek + Cabbage (2:2) & 44.78 & 6.38 & 9.35 \\
\hline $\mathbf{T}_{11}$ & Fenugreek + Radish (1:1) & 47.57 & 7.78 & 11.12 \\
\hline $\mathbf{T}_{12}$ & Fenugreek + Radish (1:2) & 45.64 & 6.89 & 10.22 \\
\hline $\mathbf{T}_{13}$ & Fenugreek + Radish (2:2) & 46.83 & 7.65 & 10.58 \\
\hline S.Em \pm & & 1.56 & 0.52 & 0.30 \\
\hline CD $5 \%$ & & 4.59 & 1.52 & 0.88 \\
\hline
\end{tabular}


Table.3 Effect of intercropping system of yield of fenugreek

\begin{tabular}{|c|c|c|c|c|}
\hline $\begin{array}{c}\text { Treatment } \\
\text { notation }\end{array}$ & Treatments & $\begin{array}{l}\text { Seed yield per } \\
\text { plant (g) }\end{array}$ & $\begin{array}{l}\text { Seed yield per } \\
\text { plot (kg) }\end{array}$ & $\begin{array}{c}\text { Estimated } \\
\text { yield }(q / h a)\end{array}$ \\
\hline$T_{1}$ & Fenugreek & 10.33 & 1.24 & 34.55 \\
\hline $\mathbf{T}_{2}$ & Carrot & - & - & - \\
\hline $\mathbf{T}_{3}$ & Cabbage & - & - & - \\
\hline $\mathbf{T}_{4}$ & Radish & - & - & - \\
\hline $\mathbf{T}_{5}$ & Fenugreek + Carrot (1:1) & 9.83 & 1.18 & 32.83 \\
\hline $\mathbf{T}_{6}$ & Fenugreek + Carrot (1:2) & 8.83 & 1.06 & 29.50 \\
\hline $\mathbf{T}_{7}$ & Fenugreek + Carrot (2:2) & 9.50 & 1.14 & 31.56 \\
\hline $\mathbf{T}_{8}$ & Fenugreek + Cabbage (1:1) & 9.20 & 1.11 & 30.92 \\
\hline $\mathbf{T}_{9}$ & Fenugreek + Cabbage (1:2) & 8.16 & 0.98 & 27.15 \\
\hline $\mathbf{T}_{10}$ & Fenugreek + Cabbage (2:2) & 8.91 & 1.07 & 29.78 \\
\hline $\mathbf{T}_{11}$ & Fenugreek + Radish (1:1) & 9.33 & 1.12 & 31.22 \\
\hline$T_{12}$ & Fenugreek + Radish (1:2) & 8.33 & 1.00 & 27.90 \\
\hline $\mathbf{T}_{13}$ & Fenugreek + Radish (2:2) & 9.17 & 1.10 & 30.83 \\
\hline S.Em \pm & & 0.29 & 0.02 & 1.27 \\
\hline CD 5\% & & 0.84 & 0.05 & 3.72 \\
\hline
\end{tabular}

The higher yield attributes and yield of fenugreek in 1:1 ratio with all intercrops might be due to less competition for space, sunlight, water and nutrients between fenugreek and component crops which gave higher growth parameters resulting in higher translocation of photosynthates from source to sink resulting in higher yield and yield attributes of fenugreek (Kumar et al., 2018).

\section{Quality attributes of fenugreek}

The result of present investigation showed that fenugreek based intercropping with different short duration vegetables viz. carrot cabbage and radish significantly affected the sole crop over other intercropping systems on the quality parameters like per cent crude protein content of fenugreek. The sole crop of fenugreek had maximum value for quality attributes i.e. per cent crude protein content of seed (21.86) and the minimum value for quality parameters i.e. per cent crude protein content of seed (17.87) was recorded under treatment $\mathrm{T}_{9}$ (fenugreek + cabbage 1:2).
However, the treatment $\mathrm{T}_{5}$ (fenugreek + carrot 1:1) and $\mathrm{T}_{7}$ (fenugreek + carrot 2:2) were found at par with treatment $\mathrm{T}_{1}$. The similar results were find by Choudhuri and Jana (2015) in intercropping of potato. In sole fenugreek the higher quality attributes was obtained due to increased availability of nutrients in the soil that might lead to synthesis and accumulation of more photosynthates (Sharma et al., 2009).

\section{References}

Choudhuri, P. and Jana, J. C. (2012). Effect of intercropping on yield and economics of cabbage. Journal of Crop and Weed, 8(1):155-157.

Choudhuri, P., \& Jana, J. C. (2015). Growth, yield, quality and economic impacts of intercropping in potato. Agri. Bio. Sci. $J, 1,6-9$.

Gliessman, S. R., 1997. Agroecology: ecological processes in sustainable agriculture. Publisher: CRC Press.

Hatfield, J. L. and D. L. Karlen, 1993. 
Sustainable agriculture systems. Publisher: CRC Press.

Kumar, A., Singh, R. and Chhillar, R.K. 2006. Nitrogen requirement of fennel (Foeniculum vulgare)-based cropping systems. Indian Journal of Agricultural Sciences, 76 (10): 599-602.

Kumar, A., Singh, R. and Chhillar, R. K. 2006. Nitrogen requirement of fennel (Foeniculum vulgare)-based cropping systems. Indian Journal of Agricultural Sciences, 76 (10): 599-602.

Kumar, V., Mehta, R. S., Meena, S. S., Parsoya, M., \& Sidh, C. N. (2018). Study on Coriander (Coriandarum sativum L.) Based Intercropping System for Enhancing System Productivity.

Mazaheri, D., A. Madani and M. Oveysi, 2006. Assessing the land equivalent ratio (LER) of two corn (Zea mays L.) varieties intercropping at various nitrogen levels in Karaj, Iran. Journal of Central European Agriculture, 7(2): 359-364.

Mehta, R. S., Singh, B., Meena, S. S., Lal, G., Singh, R. and Aishwath, O. P. (2015). Fennel (Foeniculum vulgare Mill.) based intercropping for higher system productivity. International Journal Seed Spices, 5(1):56-62.
Mehta, R. S., Meena, S. S. and Anwer, M. M. 2010. Performance of coriander (Coriandrum sativum) based intercropping system. Indian Journal of Agronomy, 55 (4): 286-289.

Rana, K. S., Pal, M. and Kumar, P. 1996. Studies on chickpea and mustard intercropping system and nitrogen fertilization under dry land conditions. Annals of Agricultural Research, 17 (3): 305-307.Rahman, M.M., T. Amano and T. Shiraiwa (2009). Nitrogen use efficiency and recovery from $\mathrm{N}$ fertilizer under rice based cropping systems. Australian Journal Crop Science, 3:336-351.

Tripathi, S. M. and Dwivedi, A. K. 2009. Economics of intercropping fennel with cauliflower. Annals of Horticulture, 2 (1): 103-105.

Varghese, L. T., Umale, S. B. and Kawthalkar, M. P. (2013). Effect of intercrops on the growth and yield of cabbage. South Indian Horticulture, 38(4):196-198

Wasaya, A., Ahmad, R., Hassan, F. U., Ansar, M., Manaf, A., and Sher, A. (2013). Enhancing crop productivity through wheat (Triticum aestivum L.) and fenugreek intercropping system. Journal Animal Plant Science, 23(1):210-215.

\section{How to cite this article:}

Akansha Verma, Kavita Aravindakshan, Sh. Rajesh Kumar Sharma, Anil K. Gupta, Rahul Chopra and Maurya, I. B. 2021. Study on Intercropping of Fenugreek (Trigonellafoenum graecum L.) with Different Short Duration Vegetable Crops. Int.J.Curr.Microbiol.App.Sci. 10(05): 95-100. doi: https://doi.org/10.20546/ijcmas.2021.1005.014 